\title{
Impact of Corporate Environmental Responsibility on Firms' Financial Performance: Moderating Role of Organizational Slack and Industry Competition
}

Naveed Iqbal Chaudhry ${ }^{1}$, Muhammad Amir Chaudhry ${ }^{2}$ Humaira Asad ${ }^{3}$ Sheeza Tahir $^{1}$

\begin{abstract}
Due to brisk trade and industry expansion in the emerging economies, it is creating severe environmental corrosion. Effluence makers' enterprises are mostly responsible for environmental deterioration. Therefore, those firms' responsibility is to take steps to control this corrosion in the environment. This research explains the effect of corporate environmental responsibility (CER) on corporate financial performance (CFP) with the moderating effect of organizational slack and industry competition. Data is collected from annual reports of $50 \mathrm{KSE} 100$ index companies from 2012-2019, containing 450 observations. A dynamic panel model is used to test the study hypothesis by using Eviews. Different pre and post estimations are applied to confirm data validity. Empirical results indicate that corporate environmental responsibility has a significant positive effect on corporate financial performance, while the organizational slack's moderating effect is negative. Industry competition has a significant positive moderating effect on the relationship, i.e., if there is high competition in the industry, firms will invest more in the environment to attract more consumers and create goodwill in the market. The study reveals that firms with high competition and focus on their responsibility towards the environment.
\end{abstract}

Keywords: Corporate Environmental Responsibility; Corporate Financial Performance; Organizational Slack; Industry Competition; Pakistan.

JEL Code: G32, L25, D22

\section{Introduction}

Nowadays, when pollution in the environment is increasing day by day, the importance of environmental protection is also enhanced. But in Pakistan, different firms take corporate environmental responsibility (CER) in different meanings, but many strategies are common in CER activities implemented by many companies (Shahid, 2012; Shah, Sarfraz, \& Ivascu, 2021). In Pakistan, there are significantly fewer practices adopted by companies for CER. Companies taking severe steps to protect their

${ }^{1}$ Department of Business Administration, University of the Punjab, Gujranwala Campus.

${ }^{2}$ Department of Commerce, University of the Punjab, Gujranwala Campus.

${ }^{3}$ Institute of Business Administration, University of the Punjab, Lahore, Pakistan.

Corresponding Author: AmirmChaudhry@gmail.com

\section{OPEN This work is Licensed under a Creative Commons Attribution-Noncommercial 4.0 International License


environment are considered the leading companies of Pakistan because of CER's efforts. According to Shahid (2012), the continuing commitment by businesses to behave ethically and contribute to economic development while improving the quality of life of the workforce and their families as well as of the local community and society at large. When trade is getting globalized, awareness for CSR is rising; further firms are adopting CSR rules. To get a standardization certificate, they invest enough money from their sales towards society and the environment. CSR is a recently launched area that still needs to be adopted rationally in Pakistan. Some researchers have shown that our country's main issue is a lack of education towards corporate environmental responsibility. Our upcoming generation is also not focusing on this issue and is only moving towards economic profit (Yunis, 2017; Sohn, Lee, \& Kim, 2020). According to Clarkson (2011), enterprises doubt whether it pays to initiate CER activities since CER requires environmental investment, reducing their profits. There is also no consensus in the literature with mixed results varying from positive, negative, or insignificant. Some factors are affecting the relationship between CER and financial performance and are ignored (Khattak \& Saiti, 2021). In this research, some factors like organizational slack and industry competition will be focused on how they affect the relationship of CER and a firm's financial performance. According to agency theory, organizational slack plays a significant role in corporate environmental responsibility as more resources will urge managers to use it for their self-interest rather than investing them towards the environment to reduce CER and ultimately financial performance (Shahzad, 2016; Kim \& Park, 2021). According to Jan Kempera (2013), Industry competition and corporate environmental responsibility have a significant association with financial performance. Firms with high growth and high CER due to innovativeness show a more significant positive effect on financial performance. (Jan Kempera, 2013). Content analysis and empirical analysis are used in this paper to know the association between CER and CFP of KSE-100 index companies. In this paper, two moderators are also focused on seeing the moderating effect of industry competition and organizational slack on the association to give theoretical input and practical indication for the companies who should focus on the fulfillment of CER and enhance their firm's financial performance. This paper is planned as follows: The second segment possesses a literature review and hypotheses, the third segment illustrates the research design, the fourth segment shows our empirical analysis, the fifth segment provides research discussions and conclusions, and in the last segment, implications are presented.

\section{Literature Review}

\subsection{Corporate Environmental Protection in Pakistan}

In discussing the matter of corporate environmental protection in Pakistan, the matter of Pakistan environmental protection act 1997 is an important thing to mention, protecting the environment from corporate activities. The primary reason behind this act's introduction is to provide protection, conservation, rehabilitation, and improvement for Pakistan's environment. This act is there to prevent pollution and promote sustainable development and conservation of Pakistan's environment, corporate environmental protection is taken as the work of aid from the companies for 
the people living in the surroundings. If a company wants to attain a competitive advantage, it is essential to do work for society and the environment. No doubt, the cost will be high in doing so. Still, it will create long-term profit for the company, which is the company's ultimate desire. Now firms are not focusing on the endorsement of their products and services only but are also focusing on environmental protection to create a positive image of their companies in stakeholders' minds (Majeed, 2015; Lee, Liu, \& $\mathrm{Yu}, 2021)$. Now many strategies are proceeding in Pakistan's firms about economic, social, and environmental enlargement to accomplish sustainable benefit. Now a day's corporate environmental protection is also treated as an investment to get long-term benefits. Regulatory pressures on organizations compel them to consider all societal, environmental, and cultural factors: without them, they can't expect long-term improvements. These pressures force them to perform their duties (Saleem, 2014).

Every country exerts different regulatory pressures on firms to force them to work by considering their surroundings and society. For example, the US government uses the technique of authorization for the fulfillment of environmental regulations. In contrast, Canada's government uses the technique of power and command structure with a diverse coating of supervision and engaging in appeasing and counseling way of persuasion (Cameron, 1993; Li, Liao, \& Albitar, 2020). Companies engage in environmental and societal analyses to avoid problems in the future. However, to lead in the industry, many firms then start imitating each other's set of laws to protect their surroundings, ultimately creating a healthy environment (Bansal, 2005). There is a vital international competitive element in environmental compliance. It is tempting for a manufacturer to operate in countries with little or no regulation. They will have lower costs. In Pakistan, many firms are playing a vital role in environmental protection. For example, Coca-Cola Company is recycling unsoiled used water (Halder, Ganguly, \& Singh, 2016). It also protects the air from gasses emitted in production. While PepsiCo provides hygienic and fitness guidance, develops water-saving policies, and carries out water sanitization trials to save the environment from harmful effects.

\subsection{Corporate Environmental Responsibility and Its Effect on Financial Performance}

The Carroll model states that the firm's primary imperative aim is to execute its worthwhile goals, then official duties, and after that, moral and altruistic aims. When firms are involved in active CER, they fulfill a set of laws and get involved in environmental protection regulations that raise their productivity by enhancing their representation and ultimately developing a competitive advantage. The government does not resolve many social matters. Hence, firms play their role in resolving social matters and getting financial success by creating a compelling value chain, publicprivate joint venture, and managing resources of the environment competently (Carroll, 2003; Kiran, 2015; Khattak \& Saiti, 2021). Owing to worldwide environmental transformation and ecological corrosion, surroundings get affected (Amir, Rehman, \& Khan, 2020). To get good performance, CER forces organizations to adopt those measures that can protect and improve surrounding and refer them to take responsibility 
for their environmental protection (Flammer, 2013; Holtbrügge, 2012; Kim \& Park, 2021). According to the natural-resource-based view (NRBV), through the positive association between natural reserves and competitive benefit, organizations must give consideration to, and yield from, the growing natural ecological confronts along with fortification. If any firm is involved in affluence, it will identify that the firm is not using its resources competently and damaging its economic performance. Simultaneously, those firms who take responsible actions to control effluence are competent to lessen their operating cost (Amir \& Chaudhry, 2019).

For the attainment of potential gains, CER is considered an asset. Firms who do high investments in green technologies and surrounding administration structures get high turnover as a reward and develop into a competent body in the industry (Hart, 2011; Lee et al., 2021). For supporting the business, it is necessary to manage the resources in such a way that CER make operations efficient, increase share prices, enhance the ecological status, potentially lessen allowable operating cost, enhance subsidies, enhance customers and investors and then ultimately create a competitive advantage (Shah, 2007). Different measures are being taken to control operating costs and contaminated costs, like installing hoods and using rigid glove boxes. According to Guenster (2011), intangible resources like a novelty, human resources, reputation, and customs are how firms can get an advantage from CER. It is observed that environmentally responsible firms enjoy high stock prices compared to those who do not consider the environment a responsibility (Belal, Cooper, \& Khan, 2015; Li et al., 2020).

Organizations that are irresponsible towards the environment face many government fines, negative reputation, pessimistic media publicity, and customer and shareholders boycott (Flammer, 2013). For example, Nestle Company faced a business defeat, brand value beating, and low stock price thrashing in 2015 due to rumors of producing unsafe Maggy food. Because of these rumors, nestle has to face a penalty from the side of the government (Wong, 2016; Shah et al., 2021). In short, organizations should pay attention to short-term turnovers and focus on sustainability and competitive advantage by taking the responsibility of surrounding defense and effluence control as it is one of the main sources to improve financial performance and reputation in the market. Following the rules and acts of corporate environmental responsibility will give dual benefits to the firms, this will not only enhance the level of positive word of mouth and goodwill for the firm but will also promote a healthy work environment in the firm, which will in turn impact the performance of the firm positively. Based on the above discussion, the following hypothesis is derived:

Hypothesis 1: Corporate environmental responsibility has a positive and significant impact on firms' financial performance.

\subsection{Moderating Role of Organizational Slack}

According to Chakrabarti (2015) "Organizational slack is the pool of resources in an organization that is in excess of the minimum necessary for a certain level of 
organizational output". Pool of resources make the firm able to manage the internal and external environment and make strategic decision in order to achieve the firm's objectives. If a firm has more slack then the managers treat it like a safeguard and start taking surrounding's issues as an opportunity instead of risk: they will not use resources in an efficient way and will start using it for their own interest instead of using them to increase the value of the firm (Chen, Zeng, Lin, \& Ma, 2017). While agency theory gives an antagonistic view and says it is unproductive and increases agency costs. If slack is in excess then it affects environmental activities and managers do not take initiative for the value addition of the firm as they start preferring their own benefits rather than shareholder's wealth maximization (Halder et al., 2016; Wu, Liang, \& Zhang, 2020). When resources are abundant then managers become risk seekers while in the presence of limited resources, they become risk reluctant (Sohn et al., 2020). If resources are abundant then managers may invest in doubtful projects like distinct mergers and acquisitions which can be harmful to financial performance. If resources are limited, then managers start avoiding unessential investments and focus on getting potential outcomes instead of loss (Ikram, Zhou, Shah, \& Liu, 2019). If managers have abundant resources, then they may become more assertive and buoyant which doesn't force them to acquire tactical measures which can save them from political and societal threats. So, an association between CER and financial performance gets weakened due to organizational slack.

Hypothesis 2: Organizational slack has a negative and significant impact between the association of CER and financial performance.

\subsection{Moderating Role of Industry Competition}

Innovation and differentiation are the main measures of industry competition which create competition and competitive advantage for the company, no study has been done yet on this variable' industry competition' to see that how it creates the link between CER and financial performance in the firms of Pakistan and researcher is going to analyze this linkage (Alessandri, Cerrato, \& Eddleston, 2018; Zeng, Gulzar, Wang, \& Zhao, 2020). Industry competition by developing a differentiated operating system to save the environment from pollution results in a positive relationship between CER and financial performance: CER greatly affects performance in less differentiated companies (Bao, Zhang, Xiao, \& Hine, 2019; H. Chen, Zeng, Lin, \& Ma, 2017; Karassin \& Bar-Haim, 2016). Ecological performance and financial performance are strongly associated, and this relationship is moderated by industry growth, which suggests that in growing industries if performance towards environment is good then the return will also be good. Differentiated product and innovativeness depicts the company's abilities and differentiates them from other companies which then moderate the relationship between financial performance and CER (Karassin \& Bar-Haim, 2016; Zhang, Wei, Zhu, \& George-Ufot, 2020). According to, Syed and Butt (2017), companies which have low capabilities actually disturb firm's value as customer get dissatisfied towards them and CSR get affected. In Australia, author found that CER entails business tactics and profitable measures which are followed by companies to 
fulfill their responsibilities towards environment and society as they are considered as an authentic tool to get competitive advantage in industry. He found the positive association between corporate capabilities and CER which ultimately enhance the financial performance of company (X. Chen, Yi, Zhang, \& Li, 2018; Hirunyawipada \& Xiong, 2018; Syed \& Butt, 2017). Industry competition and corporate environmental responsibility has significant association with financial performance, firms which have high growth and have high CER due to innovativeness show greater positive effect on financial performance (Hirunyawipada \& Xiong, 2018). In America, one of the researchers found CER is a key factor which enhances the value of the firm and creates competitive advantage for a firm which is linked with industry competition (Hong \& Shin, 2019). So, it is hypothesized that:

Hypothesis 3: Industry competition positively moderates the relationship between CER and financial performance.

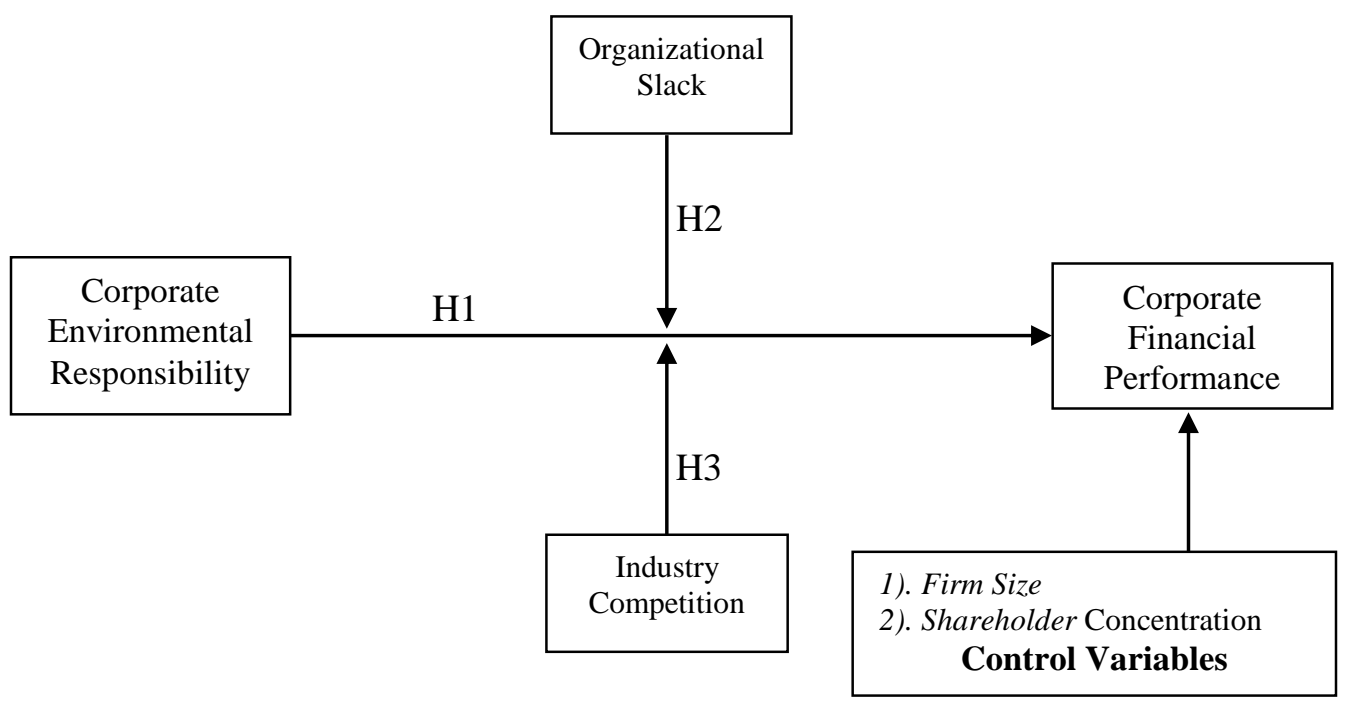

Figure 1. Conceptual Model

Above is the conceptual model of this study figure 1, the impact of corporate environmental responsibility is seen on the corporate financial performance in Pakistan. Although there are several studies that have checked the impact of corporate environmental responsibility on the corporate financial performance but there is almost no research on this issue in the context of Pakistan. Moreover, organizational slack is a significantly newly added variable, as its moderating impact is observed by the researcher. The factor of this naive moderator also adds in novelty in this study (Liu \& Ye, 2017). Moreover, the variable "Industrial competition" is also taken as a moderator between corporate environmental responsibility and the corporate financial performance, this is also a variable which has not been considered in any study in Pakistan before as a moderator between corporate environmental responsibility and the corporate financial performance.

Sukkur IBA Journal of Management and Business - SIJMB | Vol 8 No. 2 July - December 2021 @ S Sukkur IBA University 


\section{Research Methodology}

Hypothetical point of view by Belal et al. (2015) argue that the association within CG along with FP is dynamic in nature, and hence, present firm performance is influenced by the past firm performance. Torugsa (2012) has approved that the relationship between FP and CG is dynamic in nature, as well as thus dynamic endogeneity originates within variables. In this current study, to explain the association in dynamic framework. In light of methodological choice two econometric equations are developed to test the hypotheses of the study. This model is used to defined that this will deal with the problem of heterogeneity and endogeneity dynamic, state below:

$$
\begin{aligned}
& \text { CFP }_{i t}=a_{1}+B_{1} C E R_{i t}+B_{2} \text { Controls }_{i t}+\varepsilon_{1} \quad \text { Eq. (1) } \\
& \text { CFP }_{i t}=a_{1}+B_{1} \text { CER }_{i t}+B_{2} \text { Moderators }_{i t}+B_{3} \text { Controls }_{i t}+\varepsilon_{1} \text { Eq. (2) }
\end{aligned}
$$

In above mention equation the subscripts " $\mathrm{i}$ " and " $\mathrm{t}$ " denotes for firm's performance (in both dimension time and cross sessional), correspondingly, the features a panel data approach. In both case in time and cross-sectional dimensions this approach will help in two ways first one is to enhance the number of observations along with the degree of freedom, second one is, to reduce the collinearity between explanatory variables (Piao, Park, Choe, \& Baik, 2018). This model also helps to increase the reliability of inferences and estimations of current research when compared with previous studies, which mostly used cross-sectional data.

\subsection{Samples and Data Source}

The data is collected from KSE-100 index companies in which those 50 companies are selected from some specific industries for pilot testing that are very close to corporate environmental responsibility and that meet our aim and scope of our research. Names of some of those industries are power generation and distribution, fertilizers, oil and gas marketing companies, leather and tanneries, engineering, and technology \& communication. Sample period for this research is 2012-2019. Non-financial firms are selected by excluding financial firms as their capital structure is different than others and their investment strategies towards environment are also different due to not involving in pollution. Data source for each variable: corporate environmental responsibility, financial performance, organizational slack, and industry competition is annual reports of all selected companies.

\subsection{Variable measurement}

\subsubsection{Dependent variable}

Corporate financial performance (CFP): Return on equity (ROE) is considered as an authentic tool to measure corporate financial performance. Like S.-H. Tan, Habibullah, Tan, and Choon (2017) used return on equity in order to see the effect of CSR on financial performance. So, the researcher has also used ROE in this paper to see the financial performance of selected firms (Vaughan \& Koh, 2019).

Sukkur IBA Journal of Management and Business - SIJMB | Vol 8 No. 2 July - December 2021 @ Sukkur IBA University 


\subsubsection{Explanatory variable}

Corporate environmental responsibility $(C E R)$ : Many researchers used questionnaires in order to collect data for CER and they considered it the best tool to measure ( $\mathrm{Li}$ et al., 2020; Zeng et al., 2020). But there are many scholars who preferred content analysis for measuring CER by analyzing disclosed environmental information in annual reports (Jan Kempera, 2013; Melo, 2011). For measuring CER, the basic source is analyzed from the annual report which is the amount of donation which many companies are giving towards society and the environment, in the donation amount that part is separated out which is exclusively contributed towards the environment and calculated ratio by dividing the part of environmental contribution to revenue.

\subsubsection{Moderating variables}

Organizational Slack: Organizational slack is separated into two types, absorbed slack which includes repair funds, inventory, payables, etc. and unabsorbed slack which includes depreciation funds, reserve funds, corporate retention, sales costs etc. In firm's performance measurement, unabsorbed slack play an important role so it is preferred (Syed \& Butt, 2017). So, the natural logarithm of the current assets/current liabilities ratio is calculated out to measure organizational slack (Adeneye \& Ahmed, 2015). When firms have a lower ratio then it means that they have fewer resources in their hands so they will relocate resources very carefully by analyzing all needs (Asrar-ulHaq, Kuchinke, \& Iqbal, 2017). So, in this paper liquidity ratio (current ratio and quick ratio) is used to measure organizational slack (Both absorbed and unabsorbed).

Industry Competition: Industry competition is mostly measured by many companies by analyzing earnings per share as Awan, Saeed, and Management (2015), who in their research of measuring industry competition in the banking industry used EPS (Belal et al., 2015). But many scholars used market share in order to measure competition between companies in an industry where revenue of each company is divided by accumulated revenues of all companies in an industry to calculate market share (Clarkson, 2011). So, in this paper market share is used to measure industry competition.

\subsubsection{Control Variables}

Firm Size: According to Meng (2014), larger firms spend more resources towards the environment, and they have strong competition, so it also affects the relationship of CER and CFP. In this paper logarithm of total assets is taken to measure firm size.

Shareholder Concentration: According to McConnell and Servaes (1990), "If the largest shareholder had higher shareholding proportion, they would have more impacts on corporate decision-making and environmental behavior, even on the level of information disclosure". Thus, shareholder concentration affected corporate environmental behavior and financial performance significantly. 


\section{4 . Empirical Findings}

The descriptive analysis results in the current study show in the table 1 . In this study dependent variable is CFP, the independent variable is CER, moderating variables are SC and IC respectively and control variables are SIZE and SC. First of all, range of dependent variable CFP is between -0.79 to 15.66 with an average 2.088 and standard deviation of 3.89 the results are consistent with previous study of (Chtourou \& Triki, 2017). In total there are 450 observations, from which the data below is extracted.

Table 1. Descriptive Statistics

\begin{tabular}{ccccc}
\hline Variables & Mean & SD & Min & Max \\
\hline CER (IV) & 0.292 & 0.495 & 0.012 & 3.921 \\
CFP (DV) & 2.088 & 3.898 & -0.791 & 15.66 \\
OS (M) & 1.543 & 0.858 & 0.431 & 5.453 \\
IC (M) & 0.374 & 0.385 & 0.011 & 1.756 \\
SIZE (C) & 5.310 & 2.374 & 0.626 & 8.571 \\
SC (C) & 0.411 & 0.230 & 0.083 & 0.943 \\
\hline
\end{tabular}

Notes: CER: Corporate environmental responsibility, CFP: Corporate firm performance, OS: Organizational Slack, IC: Industrial competition, Size: Firm Size, SC: Shareholder Concentration.

The result of moderating variables; OS has an average 1.543 and ranges from 0.431 to 5.453 with standard deviation 5.453. IC range within 0.011 to 1.756 with standard deviation 0.35 and average of 0.374 . The descriptive analysis values clearly mention dependent variable, independent variable, moderating variables, control variable are tested for normality based on the mean values of the data, current values clearly mention current data is normal for further analysis. The minimum and maximum values are in a valid range, whereas low standard deviation shows low level of data scattering.

Table 2. Correlation Metrix

\begin{tabular}{ccccccc}
\hline Variables & CER & OS & CFP & IC & SIZE & SC \\
\hline CER (IV) & 1.0000 & & & & & \\
OS (M) & $0.4312^{* *}$ & 1.0000 & & & & \\
CFP (DV) & $0.2347^{* *}$ & $0.3629^{* *}$ & 1.0000 & & & \\
IC (M) & $0.1313^{*}$ & $0.2450^{* *}$ & $-0.2353^{* *}$ & 1.0000 & & \\
SIZE (C) & $0.1669^{*}$ & $0.1932^{* *}$ & $0.3241^{* *}$ & $0.1694^{*}$ & 1.0000 & \\
SC (C) & -0.0546 & $0.3620^{* *}$ & $0.2027^{* *}$ & $0.3860^{* *}$ & $0.1321^{*}$ & 1.0000 \\
\hline
\end{tabular}

Notes: CER: Corporate environmental responsibility, CFP: Corporate firm performance, OS: Organizational Slack, IC: Industrial competition, Size: Firm Size, SC: Shareholder Concentration. $* p<0.01, * * p<0.05, * * * p<.001$.

The portion of the study covers the discussion which is concerned with Pearson correlation matrix. The correlation matrix outcomes of independent, dependent and control variables are summarized in the above-mentioned table 2 in the paper. The results of the above table show CER is positively and significantly related with all variable OS, CEP, IC, SIZE excluding SC it also has a natively relationship role with 
CER at $1 \%$ significance level. ROE dependent variable has a positive and significant relationship with CER. The outcomes of the study show all the values are less than 10 which means it has no issues of autocorrelation.

\subsection{Results of pre-estimation tests}

Table 3. Collinearity statistics

\begin{tabular}{lcc}
\hline & VIF & Tolerance \\
\hline CER (IV) & 2.037 & .492 \\
OS (M) & 1.371 & .491 \\
CFP (DV) & 1.696 & .768 \\
IC (M) & 1.498 & .348 \\
SIZE (C) & 2.477 & .683 \\
SC (C) & 2.571 & .583 \\
Mean VIF & 1.477 & - \\
\hline Notes: CER: Corporate environmental responsibility, CFP.
\end{tabular}

Notes: CER: Corporate environmental responsibility, CFP: Corporate firm performance, OS: Organizational Slack, IC: Industrial competition, Size: Firm Size, SC: Shareholder Concentration.

The outcomes of the above table show that VIF value of each variable is not greater than 10 , that clearly shows that there is no problem of multicollinearity present among the variables. Abbreviations: CER, corporate environmental responsibility, OS, organizational slack, CEP, corporate financial performance, IC, industry competition, SIZE, firm size, SC, shareholder concentration, in the last VIF means that variance inflation factor.

Table 4. Model confirmation via Endogeneity Test

Test of endogeneity (orthogonality conditions)

$\mathrm{H} 0$ : Variables are exogenous

GMM C

H1: Variables are endogenous statistic $\chi^{2}{ }_{1}=18.6487(p=.0037)$

In the above table 4 the results of DWH test of endogeneity are showed. In the current study null hypothesis says that the variables are exogenous which are used in this study. The outcome of the current study cannot accept the HO hypothesis which means that exogenous variables are used in this mode. As for the reason that we can use now dynamic panel model to control the problem of endogeneity and further source of endogeneity. GMM represents general methods of moments, DWH represents DurbinWu-Haussmann test.

Table 5. Regression analysis

\begin{tabular}{lcc}
\hline Dependent Variable $=$ CFP & Model 1 & Model 2 \\
\hline CER & $0.287^{* *}(0.276)$ & $0.261^{* *}(0.476)$ \\
Size & $0.183^{*}(0.492)$ & $0.123^{* *}(0.283)$ \\
SC & $0.029(0.687)$ & $0.091^{*}(0.372)$ \\
CER*OS & - & $-0.119^{*}(0.294)$ \\
CER*IC & - & $0.274 * *(0.285)$
\end{tabular}

Sukkur IBA Journal of Management and Business - SIJMB | Vol 8 No. 2 July - December 2021 @ Sukkur IBA University 


$$
\text { Constant } 3.278 * *(0.943) \quad 0.637 * *(0.849)
$$

\begin{tabular}{lll}
$R^{2}$ & $0.618 * * *(0.839)$ & $0.774 * * *(0.684)$ \\
\hline Notes: CER: Corporate environtental
\end{tabular}

Notes: CER: Corporate environmental responsibility, CFP: Corporate firm performance, OS: Organizational Slack, IC: Industrial competition, Size: Firm Size, $S C$ : Shareholder Concentration. * $p<0.01, * * p<0.05, * * *<.001$.

This study has used numerous proxies for CG (CER) and for firm performance, CFP, ROE is used and SIZE, SC is used as control variables. In this study a dynamic panel model used which also called as the two-step system GMM, as it resolves the issue of multicollinearity, to control for Endogeneity problems and also to tackle macro panel data. Table 5 shows the results of the regression analysis in this study and takin about the dependent variable ROE. Outcomes of the current study clearly show there is a significant and positive association between CER and CFP, while results also show it has no association as the moderating role of OS with CER and CEP that is similar to the theory of GMM. CG and FP are dynamic in nature which is confirmed through the significant relationship between firm performance and past firm performance. in first model, CER has a positive relationship with CFP and is significant with $\mathrm{p}$ value 0.287 is less than $p$ table value. CFP also as significant with control variable Size and has an insignificant relationship with SC. In second model, CER has positive and significant relationship with the dependent variable whereas the negative and significant relationship with moderating variable OS with -0.119 . the results further show CER has positive and significant relationship with dependent variable CFP and moderating variable IC with 0.274 and has less then p value 0.005 and also has standard error is 0.285 .

\subsection{Results of post estimation tests}

Table 6. Sargan test for the validity of the model

Sargan test of over-identifying restrictions

H0: Over-identifying restrictions are $\chi 2(40)=26.56733$, Prob. $>\chi^{2}=0.7456$ valid

The current study performs a test to check the validity of the model. To identifying the overall restriction of the model the Sargan and Hensen test is run. H0 the null hypothesis stated that" over-identifying restrictions are valid." The results cannot reject the hypothesis for the validity of the model. Sargan test outcomes show it has an insignificant relationship with CER for (0.7456) that as per GMM theory accepts the null hypothesis.

\subsection{Sensitivity and robustness}

Table 7. Arellano-Bond test for the validity of regression model

\begin{tabular}{ccc}
\hline $\begin{array}{c}\text { Arellano-Bond test for zero autocorrelation } \\
\text { in first-differenced errors }\end{array}$ & H0: No autocorrelation & \\
\hline Order & $z$ & Prob. $>\mathrm{z}$ \\
\hline 1 & -2.5644 & .0032 \\
\hline
\end{tabular}

Sukkur IBA Journal of Management and Business - SIJMB | Vol 8 No. 2 July - December 2021 @ Sukkur IBA University 
In current study perform various test to check the sensitivity with the aim of supporting the outcomes of the current study. In this study a model was used with dependent variable that is CFP (firm performance). The outcomes of the regression analysis for dependent variable is given table 5 with the independent variable (CER) along with control variables (SIZE, SC). Regression analysis within firm performance and CG approves the significant influence of numerous CG features on FP.

\section{Discussion}

First, CER has positive significant relationship with CFP which is similar to previous researches like the research of Clarkson (2011) and Wong et al. (2016), while it is opposite to some researches like to Zhao and Murrell (2016) and Testa et al. (2017), they said if more resources will be used towards environment then resources of the company will get short and it will give bad impact on profit (Khattak \& Saiti, 2021; Li et al., 2020). While some researchers suggest that if the company will be involved in CER then its profit be covered by long-term revenue in the form of good reputation, committed stakeholders, more investors and enhanced financial profit. Second, OS has no moderating effect on the association between CER and CFP and it is opposite to the previous researches like J. Tan, \& Peng, M. W. (2003) he said that if organization has high resources then it will create agency problems and responsibility towards the environment will be ignored (Shah et al., 2021; Zeng et al., 2020). Our result is different from previous researches and the reason behind this different result can be small sample size and different country. If sample size will be greater than answer may become similar to previous researches. Third, industry competition has positive significant moderating effect on the association between CER and CFP which is similar to previous researches like Hull (2008), who said if competition is high in industry then it will urge companies to attract more customers and investors towards them which is possible if they provide convenience to them by providing safe environment and ultimately it will create long term revenue for the company (Kim \& Park, 2021; Lee et al., 2021; Wu et al., 2020). So, hypothesis one has been accepted as corporate environmental responsibility has a significant positive effect on corporate financial performance. Hypothesis two has also been accepted as the moderating effect of organizational slack is negative. Hypothesis three is rejected as Industry competition has significant positive moderating effect on the relationship.

\section{Conclusion}

In the current era, industries and trade are expanding in the emerging economies and also creating stern environmental corrosion. Enterprises and Effluence makers are responsible for the deterioration of the environmental. Therefore, for those firm's it's a responsibility to control this corrosion in the environment take steps. This research explained the effect of CER on CFP and explained the moderating effect of industry competition and organizational slack on the relationship. For observations, by selecting 50 companies from KSE 100 index companies from 2012 to 2019 in Pakistan, it is originated that between CER and CFP there is a significant positive correlation, and industry competition has a significant positive moderating effect, while the moderating Sukkur IBA Journal of Management and Business - SIJMB | Vol 8 No. 2 July - December 2021 @ Sukkur IBA University 
effect of organizational slack is insignificant on the relationship between CER and CFP. On basic of the findings of the study companies invest more in environment to attract consumers it there is a high competition in the industry. To attracting more customers and retaining old one's companies perform their responsibilities towards environment.

\subsection{Research Implications}

This paper is showing an important contribution to the literature. Firstly, through this paper shows the importance of environmental responsibilities. Moreover, firms' contribution towards the environment also attracts new consumers and retains old and this will show major influence on the financial and non-financial performance of the firm. Secondly, this study has shown the moderating effect of industry competition which is not shown earlier in previous studies. Thirdly, this is the first study in Pakistan which has shown the relationship of CER and CFP and this topic is of great importance in our country where environmental protection is of great need in order to improve our economic profits. Results of this study are confirming that firms can achieve financial performance as well as environmental performance simultaneously. Therefore, firms should also focus on fulfilling their responsibility towards environment during achieving economic profits. Firms should initiate the program to fulfill environmental responsibility, to create corporate environmental management system and establish evaluation system for environmental performance. Firms can make department relating to environment which work for environmental defense and control. Industry competition is an important approach to develop CER in firms. Firms can compete with each other in an industry if they will not ignore environment and society in achieving their economic goals as in the world of strong competition it is very necessary for each firm to sustain their customers and it is possible if they will give satisfaction to them by contributing towards environment.

\subsection{Limitations and Future Research Prospects}

There are some limitations in this study. This paper only explains the associations between CER and CFP, with moderators like organizational slack and industry competition, but there are many other moderators or mediators which can be studied like CEO characteristics. Future research should focus and search for deep systems and margins between CER and CFP. This study is conducted on just 50 companies from KSE 100 index, which is unable to reveal the advancement of CER and its cost. More sample size will provide more significant and clear results.

Author Contributions: Muhammad Ami Chaudhry proposed the initial conception, collected the data, analyze the data. Sheeza Tahir write the first draft of the manuscript. Dr. Humaira Asad processed the data and helped the data calculation. Dr. Naveed Iqbal gave lots of suggestions and revisions. All authors have read and agreed to the published version of the manuscript.

Data Availability Statement: The data that support the findings of this study are available upon reasonable request.

Conflict of Interest: The authors declare that they have no conflicts of interest.

Sukkur IBA Journal of Management and Business - SIJMB | Vol 8 No. 2 July - December 2021 @ Sukkur IBA University 
Funding Information: No funding was received for this research.

\section{References}

Adeneye, Y. B., \& Ahmed, M. J. J. o. B. S. Q. (2015), Corporate social responsibility and company performance. Journal of Business Studies Quarterly, Vol. 7 No. (1), pp 151166.

Alessandri, T. M., Cerrato, D., \& Eddleston, K. A. (2018), "The mixed gamble of internationalization in family and nonfamily firms: The moderating role of organizational slack", Global Strategy Journal,Vol. 8 No. (1), pp 46-72.

Amir, M., \& Chaudhry, N. I. (2019), "Linking environmental strategy to firm performance: A sequential mediation model via environmental management accounting and top management commitment", Pakistan Journal of Commerce and Social Sciences (PJCSS),Vol. 13 No. (4), pp 849-867.

Amir, M., Rehman, S. A., \& Khan, M. I. (2020), "Mediating role of environmental management accounting and control system between top management commitment and environmental performance: A legitimacy theory", Journal of Management and Research,Vol. 7 No. (1), pp 132-160.

Asrar-ul-Haq, M., Kuchinke, K. P., \& Iqbal, A. J. J. o. C. P. (2017), "The relationship between corporate social responsibility, job satisfaction, and organizational commitment: Case of Pakistani higher education",Vol. 142 No. (4), pp 2352-2363.

Awan, A. G., Saeed, S. J. E. J. o. B., \& Management. (2015), "Impact of CSR on firms' financial performance: a case study of ghee and fertilizer industry in Southern PunjabPakistan",Vol. 7 No. (7), pp 375-384.

Bansal. (2005), " Evolving sustainably: A longitudinal study of corporate sustainable development", Strategic Management Journal Vol. 26 No. (3), pp 197-218.

Bao, G., Zhang, W., Xiao, Z., \& Hine, D. (2019), "Slack resources and growth performance: The mediating roles of product and process innovation capabilities", Asian Journal of Technology Innovation Vol. 28 No. (1), pp 60-76.

Belal, A. R., Cooper, S. M., \& Khan, N. A. J. C. P. o. A. (2015), "Corporate environmental responsibility and accountability: what chance in vulnerable Bangladesh?",Vol. 33 No (1)., pp 44-58.

Cameron. (1993), "Environmental concerns in business transactions: Avoiding the risks", Butterworths Publisher.

Carroll. (2003) "Corporate social responsibility: A three-domain approach." Business ethics quarterly (2003): 503-530

Chakrabarti, S. (Producer). (2015, July 9). Nestle punished by government. Why govt was grievously wrong on Maggi and how much Nestlé should be compensated. Retrieved from https://blogs.economictimes.indiatimes.com/TheContrarianCapitalist/why-govtwas-grievously-wrong-on-maggi-why-and-how-much-nestle-should-be-compensated/

Chen, H., Zeng, S., Lin, H., \& Ma, H. (2017), "Munificence, dynamism, and complexity: How industry context drives corporate sustainability", Business Strategy and the Environment, Vol. 26 No. (2), pp 125-141.

Chen, X., Yi, N., Zhang, L., \& Li, D. (2018), "Does institutional pressure foster corporate green innovation? Evidence from China's top 100 companies", Journal of cleaner production, Vol. 188 No. (3), pp 304-311.

Chtourou, H., \& Triki, M. J. S. R. J. (2017), "Commitment in corporate social responsibility and financial performance: a study in the Tunisian context", Social Responsibility Journal, Vol. 13 No. (2), pp. 370-389. https://doi.org/10.1108/SRJ-05-2016-0079

Sukkur IBA Journal of Management and Business - SIJMB | Vol 8 No. 2 July - December 2021 C Sukkur IBA University 
Clarkson, P. M., Li, Y., Richardson, G. D. (2011), "Does it really pay to be green? Determinants and consequences of proactive environmental strategies", Accounting and Public Policy Vol. 30 No.(2), pp 122-144.

Coca Cola. Coca Cola's role in community. Retrieved from http://www.cocacolacompany.com/our-company/the-coca-cola-foundation

Flammer. (2013), "Corporate social responsibility and shareholder reaction: The environmental awareness of investors", Academy of Management Journal Vol. 56 No. (3), pp 758-781.

Guenster, N., Bauer, R., Derwall, J. (2011), "The economic value of corporate eco-efficiency", European Financial Management Vol. 17 No. (4), pp 679-704.

Halder, S., Ganguly, D., \& Singh, V. P. J. I. J. o. A. P. T. (2016), "Design Process and Its Application on the Improvement (Re-Design) of the Coke Bottle",Vol. 4 No. (1), pp 185199.

Hart, S. L., \& Dowell, G. (2011), " A natural-resource-based view of the firm: Fifteen years after", Journal of Management Vol. 37 No. (5), pp 1464-1479.

Hirunyawipada, T., \& Xiong, G. (2018), "Corporate environmental commitment and financial performance: Moderating effects of marketing and operations capabilities", Journal of Business Research,Vol. 86 No., pp 22-31.

Holtbrügge, D., C. (2012), "How international is corporate environmental responsibility? A literature review", Journal of International Management Vol. 18 No. (2), pp 180-185.

Hong, S., \& Shin, H.-D. (2019), "Organizational slack and innovativeness: the moderating role of institutional transition in the Asian financial crisis", Asian Business \& Management Vol 19 No. (1), pp 1-20. DOI. https://doi.org/10.1057/s41291-019-00094-y

Ikram, M., Zhou, P., Shah, S., \& Liu, G. J. J. o. C. P. (2019), "Do environmental management systems help improve corporate sustainable development? Evidence from manufacturing companies in Pakistan",Vol. 226 No., pp 628-641.

Jan Kempera, O. r., Martin Reimann, Xuyi Wang, Malte Brettel. (2013), " Competitionmotivated corporate social responsibility. Journal of Business Research, 66(10), pp 19541963.

Karassin, O., \& Bar-Haim, A. J. J. o. E. M. (2016), "Multilevel corporate environmental responsibility",Vol. 183 No. (1), pp 110-120.

Khattak, M. A., \& Saiti, B. (2021). Banks' environmental policy and business outcomes: The role of competition. Business Strategy and the Environment, 30(1), 302-317.

Kim, H.-D., \& Park, K. (2021). Impact of Environmental Disaster Movies on Corporate Environmental and Financial Performance. Sustainability, 13(2), 559.

Kiran, S. (2015), "Corporate Social Responsibility and Firm Profitability: A Case Of Oiland Gas Sector Of Pakistan", City University Research Journal Vol. 5 No.(1), pp 111-113.

Lee, T., Liu, W. T., \& Yu, J. X. (2021). Does TMT composition matter to environmental policy and firm performance? The role of organizational slack. Corporate Social Responsibility and Environmental Management, 28(1), 196-213.

Li, Z., Liao, G., \& Albitar, K. (2020). Does corporate environmental responsibility engagement affect firm value? The mediating role of corporate innovation. Business Strategy and the Environment, 29(3), 1045-1055.

Liu, M., \& Ye, S. (2017). The Moderating Effect of Equity Incentive on Slack and R \& D Investment. Paper presented at the 2017 3rd International Conference on Humanities and Social Science Research (ICHSSR 2017).

Majeed, S. (2015), "The Effect of Corporate Governance Elements on Corporate", International Journal of Financial Studies Vol. 3 No. (4), pp 532-533.

Melo, T. (2011), Corporate reputation: A combination of social responsibility and industry. Corporate social responsibility and environmental management, Vol. 19 (1), pp 11-31.

Sukkur IBA Journal of Management and Business - SIJMB | Vol 8 No. 2 July - December 2021 (C) Sukkur IBA University 
Meng, X. H., Zeng, S. X., Shi,. (2014), "The relationship between corporate environmental performance and environmental disclosure: An empirical study in china", Journal of Environmental Management Vol 145 No. (1), pp 357-367.

Piao, Y., Park, Y.-R., Choe, S., \& Baik, Y. (2018), "International Aspects of Corporate Governance and Corporate Social Performance of Chinese Listed Firms: Moderating Effect of Organizational Slack", 국제경 영연구,Vol. 29 No. (3), pp 85-112.

Saleem, F. (2014), "Impact of Institutional Forces and Availability of Slack on Corporate Environmental Behavior: Evidence from a Developing Country ", Pakistan Journal of Commerce and Social Sciences Vol 8 No. (2), pp 366-367.

Shah, K. U., \& Rivera, J. E. (2007), " Export processing zones and corporate environmental performance in emerging economies", Policy Sciences Vol. 40 No. (4), pp 265-285.

Shah, S. G. M., Sarfraz, M., \& Ivascu, L. (2021). Assessing the interrelationship corporate environmental responsibility, innovative strategies, cognitive and hierarchical CEO: A stakeholder theory perspective. Corporate Social Responsibility and Environmental Management, 28(1), 457-473.

Shahid (Producer). (2012, January 15). CSR in Pakistan. Corporate Social Responsibility in Pakistan. Retrieved from https://www.pakistantoday.com.pk/2012/01/15/corporatesocial-responsibility-in-pakistan/

Shahzad, A. M., Mousa, F. T. (2016), "The implications of slack heterogeneity for the slackresources and corporate social performance relationship", Journal of business research Vol. 69 No. (12), pp 5964.

Sohn, J., Lee, J., \& Kim, N. (2020). Going Green Inside and Out: Corporate Environmental Responsibility and Financial Performance under Regulatory Stringency. Sustainability, 12(9), 3850.

Syed, M. A., \& Butt, S. A. J. S. R. J. (2017), "Financial and non-financial determinants of corporate social responsibility: empirical evidence from Pakistan", Social Responsibility Journal, Vol. 13 No. 4, pp. 780-797. https://doi.org/10.1108/SRJ-08-2016-0146

Tan, J., \& Peng, M. W. (2003), " Organizational slack and firm performance during economic transitions: Two studies from an emerging economy.", Strategic Management Journal Vol 24 No. (13), pp 1249-1263.

Tan, S.-H., Habibullah, M. S., Tan, S.-K., \& Choon, S.-W. (2017), "The impact of the dimensions of environmental performance on firm performance in travel and tourism industry", Journal of environmental management,Vol. 203 No. (1), pp 603-611.

Torugsa, N. A. (2012), "Capabilities, proactive CSR and financial performance in SMEs: Empirical evidence from an Australian manufacturing industry sector." Journal of business ethics, 109 (4), 483-500.

Vaughan, Y., \& Koh, Y. (2019), "Role of resource slack in rapid international expansion of restaurant companies", International Journal of Contemporary Hospitality Management, Vol. 31 No. (1), pp. 2-20. https://doi.org/10.1108/IJCHM-07-2017-0415

Wong, C. W., Miao, X., Cui, S., \& Tang, Y. (2016), Impact of corporate environmental responsibility on operating income: Moderating role of regional disparities in China. Journal of Business Ethics, Vol. 149 No. (2), 363-382.

Wu, W., Liang, Z., \& Zhang, Q. (2020). Effects of corporate environmental responsibility strength and concern on innovation performance: The moderating role of firm visibility. Corporate Social Responsibility and Environmental Management, Vol. 27 No. (3), 14871497. 
Yunis, M. S. (2017), "Corporate Social Responsibility (CSR) in Pakistan:A Critique of the Literature and Future Research agenda", Business \& Economic Review Vol. 9 No. (1). 65-88.

Zeng, Y., Gulzar, M. A., Wang, Z., \& Zhao, X. (2020). The effect of expected financial performance on corporate environmental responsibility disclosure: evidence from China. Environmental Science and Pollution Research, Vol. 27 No. (30), 37946-37962.

Zhang, Y., Wei, J., Zhu, Y., \& George-Ufot, G. (2020). Untangling the relationship between Corporate Environmental Performance and Corporate Financial Performance: The double-edged moderating effects of environmental uncertainty. Journal of Cleaner Production, Vol. 263 No. (1), 121584. 